\title{
Improvement And Modernization of Agricultural Irrigation. Uzbekistan Case Study
}

\author{
Olim Rkahimov, Obidjon H. Khamidov and T. S. Cuesta
}

\begin{abstract}
This paper analyzes the history and present of irrigation in agriculture in Uzbekistan to set future goals. The changes produced in the economic and political reality in Central Asia in this past century are of great importance for water management in the Aral Sea basin. This framework also considers the relationships between countries that share water resources. Changes in the market economy, the need to diversify the Uzbek economy, and the need to produce food make inevitable changes in water management. It is essential to address the modernization and improvement of the irrigation systems of Uzbekistan.
\end{abstract}

Index Terms - Irrigation, agriculture, modernization, water resources.

\section{INTRODUCTION}

The study area of this paper is the Republic of Uzbekistan. Uzbekistan covers an area of $447.400 \mathrm{~km}^{2}$ and it is located in Central Asia. It limits Kazakhstan to the north and northeast, Turkmenistan to the southwest, Afghanistan to the south, Tajikistan to the southeast and Kyrgyzstan to the northeast. (Fig. 1). The study area is furrowed by the Syr Darya river, which rises in the Tian Shan mountain range and the Amu Darya river, which rises in the Pamir [1]. Both rivers flow into the Aral Sea, whose desertification is the greatest ecological catastrophe in the region [2].

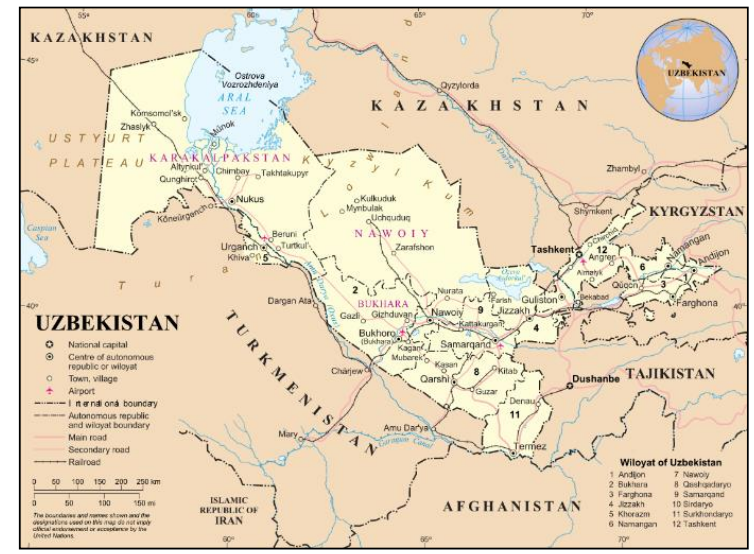

Fig. 1. Location of the Republic of Uzbekistan.

The main agricultural areas border the Syr Darya and Amu Darya rivers, highlighting the Ferganá valley, the Zerafshan river and Chirchik river basins, and some areas of the Amu

Published on August 21, 2020.

O. K. Rakhimov, Faculty of Economics and Tourism, Bukhara State University, Uzbekistan.

(e-mail: buxdu_moliya@mail.ru).

O. H. Khamidov, Faculty of Economics and Tourism, Bukhara State University, Uzbekistan.

\section{Darya basin.}

The average annual precipitation is $264 \mathrm{~mm}$, it presents great territorial variations [3]. From $97 \mathrm{~mm}$ in the northwest to $425 \mathrm{~mm}$ in the mountainous regions. Rainfall occurs during the winter, mainly between October and April. There are high temperatures $42-47^{\circ} \mathrm{C}$ on the plains and $25-30^{\circ} \mathrm{C}$ in the mountainous regions in July, and low temperatures in winter, minus $11^{\circ} \mathrm{C}$ in the north and $2-3^{\circ} \mathrm{C}$ in the south in January. Because of frequent frosts, between late September and April, only one crop a year can be grown.

In 2018, the cultivated area was an estimated 4,65 million ha, of which $92,5 \%$ was under temporary crops and 7,5\% under permanent [4]. Only $18 \%$ of the cultivable area, an estimated 25,4 million ha, is cultivated because of the water shortage. Agriculture in Uzbekistan represents 19,2\% of GDP, $46 \%$ of employment and $60 \%$ of foreign exchange earnings [5]. The base of agricultural production is irrigated agriculture with almost $82 \%$ of agricultural land. Cotton and wheat are the main crops, although it is also worth mentioning the cultivation of cherries and grapefruits for their high added value [6].

Water is a vital element for all spheres of socio-economic activity, a vital natural resource for the life and activity of households, agricultural producers and other enterprises, as well as for maintaining the ecological balance [7]. According to the UN classification, Uzbekistan is one of the countries experiencing water shortages [8]. It is estimated that a 10$20 \%$ reduction in water supply could have serious consequences for the size and size of irrigated land. This decrease would lead to a decrease in national income.

Within this framework, the main objective of the development of water resources in the Republic of Uzbekistan is to create the necessary conditions to meet the growing needs of the population [5]. These needs are very important in the sectors of the economy and the environment. It is important to ensure effective management and rational use of water resources. Furthermore, it is worth highlighting the improvement in the recovery of irrigated lands, the increased efficiency in the use of water resources, water management and food security in the face of growing deficits and global climate change.

The future of Uzbekistan's water economy is determined by efforts in the field of water resource management and the importance of international cooperation in the use of transboundary rivers [8]. In this case, climate change is an important factor in guaranteeing the supply and security of

(e-mail: obidjon2006@yahoo.com).

T. S. Cuesta, Agricultural and Forestry Engineering Department, University of Santiago de Compostela, Spain.

(e-mail: tomas.cuesta@usc.es) 
water in the future.

In this scenario, the decrease in water supply is worrisome due to the reduction in the contributions of rivers and groundwater. Therefore, to meet the economic and environmental needs of water, it is necessary to increase efficiency [4]. The application of integrated water management practices can lead to greater cooperation between different users.

The main source of water resources for irrigation is agriculture, which represents up to $90 \%$ of water consumption in the country. Farmers have great potential to increase water use efficiency and on-farm productivity. It is necessary to undertake the improvement and modernization of irrigation infrastructures.

\section{DISCUSSION}

\section{A. Threats due to climate change and consequences on regional relations}

Climate change is accompanied by an increase in ambient temperature during the hot summer months and an increase in the number of years of water scarcity. This situation causes the region to intensify floods and other natural phenomena. This is due to the increased intensity of rainfall during certain periods of the year [9].

As in Central Asia, climate change in Uzbekistan manifests itself directly in the disappearance of existing snow masses in mountain ranges [10]. These masses constitute the supply of the main rivers of the region. In the last 50 years, glaciers have been reduced by approximately $30 \%$. It is estimated that when the temperature increases by $2{ }^{\circ} \mathrm{C}$, the volume of ice will decrease by $50 \%$, and by $4{ }^{\circ} \mathrm{C}$, by $78 \%$. Such melting of glaciers could lead to severe water shortages. According to estimates, by 2050 the flow in the Syr Darya basin is expected to decrease by $5 \%$, and in the Amu Darya basin by $15 \%$. For 2015 , the total water deficit in Uzbekistan will be more than $3 \mathrm{~km}^{3}$, by 2030 it will increase to $7 \mathrm{~km}^{3}$ and by $2050,15 \mathrm{~km}^{3}$.

Assessments carried out with the help of global climate models show that climate change will exacerbate water scarcity in Uzbekistan [11]. This will lead to an increase in the duration and duration of droughts in 2000, 2008, 2011, 2014 and 2018. Meeting the economy's needs for water resources during droughts can be critical to the country.

The water scarcity situation is further complicated by the fact that Uzbekistan is highly dependent on the water supply from neighboring countries [9]. That is why Uzbekistan is establishing water relations with neighboring countries multilaterally and bilaterally.

In recent years, water relations between the two countries have improved significantly. There is a positive trend in addressing the problems of transboundary water use. The construction of new hydroelectric facilities and water reservoirs on the upper reaches of the Amu Darya River and the Syr Darya will help develop the Central Asia region, including Uzbekistan. Currently, existing water resources are not fully utilized. This allows for further development in the areas irrigated by the Amu Darya River and the Syr Darya River. It should also be borne in mind that the Aral Sea Basin needs to improve its legal research framework for the use of water resources [2].

\section{B. Institutional problems of water management}

The main institutional problems of water management in Uzbekistan are the lack of incentives for water users. The users are mainly agricultural producers and individuals, those responsible for the infrastructures and those organized by their management [8]. One reason may be that water users and the public do not participate in water resource management and do not have free access to information on water use.

Until now, administrative methods have dominated the management of water supply in the agricultural sector, without considering market factors. The main means of water distribution are based on quotas and administrative controls. The tasks of implementing cotton production and processing plans were not linked to maximizing economic benefits. It was also important to study the increase in income, in the efficiency of water use in agriculture and in reducing the cost of water supply. The main costs of water supply for agricultural producers are covered by the state budget. Payments for water supply by agricultural producers are not directly related to the amount of consumption. Its quantity is not enough to encourage efficient and economical water consumption [10]. The management of the trunk and intercultural infrastructure is carried out mainly by the structures of the Ministry of Water Resources and is financed from the state budget. Implementers do not have sufficient incentives to save on the cost of introducing water and energy saving technologies, maintenance and modernizing infrastructure [4]. Public-private partnership practices are not yet sufficiently applied in the sector. Water consumer associations have been created to manage and distribute water effectively in the farm's internal irrigation networks. But it has not yet been possible to create a sustainable structure for the self-management of water consumers.

The lack of efficiency of the work of the water consumers associations has caused a deterioration and obsolescence in the technical conditions of the irrigation networks and their hydraulic structures [6]. In addition, water supply services, in quantity and quality, have not been provided to farms.

This situation reflects a problem in planning the irrigated area. The average annual expenditure on irrigation is 60 billion USD to irrigate 4.250 thousand hectares [5]. Water is transported through open channels with increasing demand. This increase is a consequence of population growth, the expansion of new industries and construction.

Water losses in the water transport and distribution network are very high. Transport efficiency is $0,5-0,6$. This indicates that more than $40-50 \%$ of the water is lost before reaching the farm. Increasing the efficiency of transportation and irrigation systems is one of the important opportunities to save water [12]. If we carry out irrigation in accordance with all agrotechnical and recovery requirements, this ratio can be increased to at least $0,85-0,9$.

\section{New challenges}

The efficiency in the use of water is conditioned by the transport systems (modernization) and by the distribution systems (improvement) [12]. It is necessary to consider improvements in the transportation network, modernizing the distribution network [4]. And it is necessary to change the irrigation systems to adapt the irrigation doses, reduce water 
consumption and avoid salinity of soils.

The efficient use of every cubic meter of water consumed remains an important scientific and practical problem. In recent years, the effective use of irrigation systems and reclamation funds; has been a priority in solving the problem [9]. Careful maintenance, systematic repair and rational use of irrigation facilities, facilities and systems are carried out at the expense of the state budget.

Loss of water at irrigation points leads to waste of water and causes extensive material damage. This problem worsens groundwater levels, salinizes soils, and worsens the recovery status of irrigated land. In addition, water losses force oversize transport infrastructure.

According to the data, as of January 1, 2018 [4], there are in Uzbekistan 4,3 million hectares of agricultural land and 2,2 million hectares of irrigated arable land with varying degrees of salinity (Table 2).

TABLE I: SOIL SALINITY IN UZBEKISTAN

\begin{tabular}{lll}
\hline \hline Degree of salinity & $10^{3}$ hectares & $\%$ \\
\hline Low & 1,373 & 62.5 \\
Medium & 664 & 30.0 \\
High & 163 & 7.5 \\
\hline \hline
\end{tabular}

Steps are being taken to radically reform water use mechanisms, ensure their rational and efficient use, support and encourage the introduction of water saving technologies in various sectors of the economy. According reference [13], this will allow the recovery of irrigated land.

The measures taken, and the state support mechanisms, allowed the introduction of irrigation technologies that save water on 33.2 thousand hectares in 2019 alone [14]. However, the area where new irrigation technologies are applied represents only $1.7 \%$ of the total area of irrigated land. For this reason, further intensification of measures is required to expand the use of water saving technologies in agriculture and guarantee water efficiency [10].

Modernization and improvement of irrigation is necessary [13]. In other words, it is necessary to adopt new techniques for water distribution within the farm and to improve water distribution networks.

The advantages of using a modern drip irrigation system derive from the fact that only the root part of the plant is moistened. Therefore, the amount of water lost due to evaporation, runoff and deep percolation is reduced [15]. Water consumption per hectare of cotton is 3,5 thousand $\mathrm{m}^{3}$ in drip irrigation, 8,5-9 thousand $\mathrm{m}^{3}$ in conventional irrigation, which saves $5-5,5$ thousand $\mathrm{m}^{3}$ or $60-65 \%$ of water. Table 2 shows the results, expressed in thousands of soum, of the transformation into drip irrigation in the cotton crop of the "Rustam Fayz" farm in the Gijduvon district [10].

TABLE II: NET PROFIT PER HECTARE $\left(10^{3}\right.$ SOUM $)$

\begin{tabular}{llll}
\hline \hline Concept & $\begin{array}{l}\text { Surface } \\
\text { Irrigation }\end{array}$ & $\begin{array}{l}\text { Drip } \\
\text { Irrigation }\end{array}$ & Difference \\
\hline Cost per hectare & 9,207 & 13,097 & 3,890 \\
Income per hectare & 9,425 & 14,625 & 5,200 \\
Net Profit per hectare & 268 & 1,528 & 1,260 \\
\hline \hline
\end{tabular}

According to tests carried out in the field [10] and [4], drip irrigation saves energy, labor, fuel, and fertilizers. Since this technique requires less water, less electricity or diesel is used to operate the pumps. Irrigation costs per hectare of cotton are 2,5-3 times.

For a hectare of cotton cultivation with surface irrigation, $800 \mathrm{~kg}$ of nitrogen, $150 \mathrm{~kg}$ of phosphorus and $100 \mathrm{~kg}$ of potassium are needed. On the contrary, for a hectare in drip irrigation $300 \mathrm{~kg}$ of nitrogen, $150 \mathrm{~kg}$ of phosphorus and $50 \mathrm{of}$ potassium are used. This is because in drip irrigation the absorption of mineral fertilizers is $90-95 \%$ and only $30-38 \%$ in conventional irrigation. During irrigation, dissolved fertilizers enter the root zone directly and nutrients are quickly absorbed.

With early maturation of the crop, high yield and product quality are observed in drip irrigation. Due to the precise entry of moisture into the plant root system and the complete assimilation of fertilizers, the yield is $50-55 \%$ higher than with conventional irrigation.

Drip irrigation does not require drainage infrastructure, so arable land is increased by an area of $10 \%$. In addition, the soil structure is preserved since salts do not rise with the rise of the groundwater level.

The different absorption of water in the soil allows irrigation with very uneven surfaces. The location of the irrigation drippers at the top of the furrows facilitates the mechanization of the soil. The soil between the rows remains dry throughout the season, facilitating the movement of farm machinery and workers.

This irrigation technique favors the growth control of adventitious weeds. In addition, the cotton root develops well, many active radical hairs are formed, and the rate of nutrient consumption with water increases.

In this sense, in the Decree of the President of the Republic of Uzbekistan "On measures for the efficient use of land and water resources in agriculture" [16], approved in 2019 as a future objective the introduction of new irrigation technologies on 253,381 hectares for the period 2019-2022.

TABLE III: FORECAST INDICATORS (HECTARES)

\begin{tabular}{lll}
\hline \hline Districts & $\begin{array}{l}\text { Total cotton } \\
\text { fields }\end{array}$ & $\begin{array}{l}\text { Forecast indicators } \\
\text { of drip irrigation }\end{array}$ \\
\hline Bukhara & 8,558 & 400 \\
Vobkent & 9,560 & 400 \\
Jondor & 11,910 & 400 \\
Kogon & 6,722 & 500 \\
Karakul & 8,758 & 600 \\
Korovulbozor & 4,965 & 300 \\
Olot & 7,851 & 1,000 \\
Peshku & 8,120 & 500 \\
Romitan & 10,845 & 1,000 \\
Shofirkon & 9,247 & 400 \\
Gijduvon & 9,744 & 500 \\
Bukhara city & 12,050 & 0 \\
TOTAL district & 96.400 & 6,000 \\
\hline \hline
\end{tabular}

Table III shows the target set in 2019 for the introduction of drip irrigation in cotton fields in the districts of the Bukhara region.

As a result of this program, the area of critical groundwater levels up to 2 meters has been reduced by 364,6 thousand hectares. In the Republic of Karakalpakstan, this figure decreased by 59,1 thousand hectares, 45,6 thousand hectares in the Syrdarya region, 46,2 thousand hectares in the Tashkent region and 34,4 thousand hectares in the Bukhara district [14]. This decrease in water levels has allowed an 
increase in cotton yields from 2 to 4 quintals per hectare and in cereals from 4 to 6 quintals per hectare [10].

In the areas where land reclamations were executed, the area of strong and moderate salinity decreased by 81,2 thousand hectares. This improvement can be quantified by measuring the level of groundwater mineralization that decreased. The groundwater area with a mineralization level of up to $1 \mathrm{~g} /$ meter increased by 74 thousand hectares.

In recent years, 753 billion soums have been allocated for the implementation of the Program. (equivalent to about 792 thousand USD), of which 312,2 billion souls were allocated for investment projects, 315,6 billion soums for soum repair and restoration and 125,7 billion soums for the purchase of recovery equipment.

As a result, all measures to improve the reclamation of lands under the program have been fully implemented. The task now is to prevent the deterioration of land reclamation and to prevent the deterioration of land reclamation.

The state is focusing on the implementation of measures to improve and repair the irrigation and irrigation system for 2021-2025. It is also to introduce a mechanism to encourage the development and widespread implementation of modern technologies for drip irrigation and other advanced water conservation. Strict measures should be taken to introduce market mechanisms in water resources management. The use of drip irrigation and other non-traditional methods should improve the quality of agro-technical measures in this regard.

\section{CONCLUSIONS}

As a result of this research we highlight several alternatives to increase the efficiency in the use of water in agriculture.

The state must undertake the improvement of water distribution infrastructures. It is important to act on the main and secondary channels and the improvement of dams and reservoirs.

It is important to improve the efficiency of drainage networks and pumping stations.

It is necessary to increase the rational use of water resources, reducing evaporation and water filtration.

To reduce irrigation doses, it is necessary to modify the water application systems on the plot. Surface irrigation is currently used with excessive water application. Cheaper irrigation methods such as drip irrigation, sprinkler irrigation and the widespread use of underground irrigation should be used.

We do not only have to resort to technical or scientific measures. It is also necessary to modify the economic management of irrigation water. We have to assess the cost of installations in irrigation systems and introduce depreciation allocation principles. In this line of work, it is necessary to establish the price per unit (hectare or cubic meters) for the wastewater supplied through the irrigation system.

Finally, it is necessary to strengthen the state's regulatory policy in water management in relation to the conservation of land and water resources.

In order to increase the efficiency of the main irrigation, irrigation and reclamation funds in the water management construction complex, it is necessary to pay close attention to clearly defining the rate of depreciation.
Therefore, future lines should include aspects such as the computerization of water supply and reservoir facilities, the establishment of open and closed canals and collectors, new pumping stations and drainage facilities and energy supply networks. For this it is necessary to define with scientific criteria the competencies and functions of the elements necessary for water management. And it is necessary to introduce a scientific understanding of economic concepts related to water management.

\section{REFERENCES}

[1] N. A. Kogay, Physical and geographical zoning of the Turan part of Central Asia. Tashkent, Uz.:1969, pp. 2-7.

[2] M. Bekchanov, C. Ringler, and A. Bhaduri, "A Water Rights Trading Approach to Increasing Inflows to the Aral Sea", Land Degradation \& Development, vol. 29 (4), pp. 952-961, 2018.

[3] H. R. Toshov, and I. E. Mirzaev, "Climate and economy: its consequences on the example of the Bukhara region", Republican Scientific-methodological and Educational Journal, vol. 2 (18), pp. 11 $13,2016$.

[4] O. Rakhimov, and D. Yavmutov, "Economics of agro-industrial complex: agricultural land and water resources and their use" in Economics: agriculture, microeconomics, macroeconomics. Tashkent, Uz.: 2019, pp. 64-79.

[5] O. Rakhimov, and A. Abdughaniyev, "Management of water resources and their division problems in Central Asian region" presented at the V Congress National and II Congress Ibérico Agroingeniería, Lugo (Spain) September 28-30, 2009.

[6] I. Abdullaev, J. Kazbekov, H. Manthritilake, and K. Jumaboev, "Water User Groups in Central Asia: Emerging Form of Collective Action in Irrigation", Water Management. Water Resources Management, vol. 24(5), pp. 1029-1043, 2009.

[7] O. Rakhimov, D. Sh. Yavmutov, and K. R. Toshov. Natural geographical description, land and water fund of Bukhara region. Bukhara, Uz.: Bukhara State University, 2019, pp. 6-11.

[8] FAOSTAT (May 2020). Production of Cotton by countries. Available: http://www.fao.org/faostat/en/\#data.

[9] V. Sokolov, 25 Years of activities International Fund for Saving the Aral Sea and new impulses for development of the Aral Sea Region, Taskhent, Uz.: Agency of International Fund for Saving the Aral Sea, 2019.

[10] Ministry of Water Resources (May 2020). Ministry of Water Resources of the Republic of Uzbekistan. Available: http://www.water.gov.uz/uz.

[11] World Bank, Strengthening Analysis for Integrated Water Resources Management in Central Asia: A Road Map for Action. Washington D. C.: EEUU: Main Report WB, 2013.

[12] X. X. Neira, C. J. Álvarez, T. S. Cuesta, and J. J. Cancela. "Evaluation of water use in traditional irrigation: an application to the Lemos valley irrigation district, northwest of Spain", Agricultural Water Management vol. 75 (2), pp. 137-151, 2005.

[13] D. Sh. Yavmutov, and O. Rakhimov, "Elaboration of regional strategies for the development and improvement of land and water in agriculture", Academy, vol. 2 (53), 2020.

[14] CAWater-IS (April 2020). Regional Information System on Water and Land Resources in the Aral Sea Basin. Available: http://cawaterinfo.net/bd/index_e.htm.

[15] Z. Ai, Y. Yang, Q. Wang, K. Manevski, Q. Wang, Q. Hu, D. Eer, and J. Wang, "Characteristics and influencing factors of crop coefficient for drip-irrigated cotton under plastic-mulched condition in arid environment", Journal of Agricultural, vol. 74 (1), pp.1-8. 2018.

[16] National Agency of Project Management, "On measures for the efficient use of land and water resources in agriculture", Decree of the President of the Republic of Uzbekistan of June 17, 2019 No. PF-5742. Taskent, Uz. 2019.

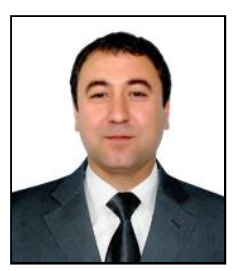

Olim Rakhimov was born on December 1, 1975 in Vobkent, a district in the Bukhara region. He graduated with a degree in Economics, AgroEconomics, from Bukhara State University (BSU) in 1997.

From 2001 to 2005 he is a professor in the Department of Economics at BSU. In 2007, he obtained the scholarship of the Foundation of the President of the Republic of Uzbekistan "Iste'dod" and obtained the title "Innovational Management" from Moscow State University. 
Between 2005 and 2008 he carried out postgraduate studies in the Department of Economics at BSU and between 2008 and 2010 he completed and obtained the Diploma of Advanced Studies from the University of Santiago de Compostela, Spain.

Between 2010 and 2012, professor at the Department of Economics at BSU.

Since 2014, he has held the position of Vice-Chancellor for Economic and Financial Affairs at Bukhara State University. 